\title{
Histology of Rat Pancreas Treated with Calliandra calothyrsus Leaf in the Diets during Pregnancy and Lactation
}

\author{
Iriani Setyawati \\ Study Program of Biology, Faculty of Mathematics and Natural Sciences, Udayana University, Bali, Indonesia \\ Email: iriani_setyawati@unud.ac.id
}

\begin{abstract}
For cattle, red calliandra (Calliandra calothyrsus) is a good protein source of forage but the condensed tannin content is the highest compared to other legume plants. Tannin can reduce the activity of digestive enzymes and protein digestibility, which can lead to pancreatic hypertrophy and hyperplasia. This study aimed to determine the pancreatic histology of pregnant rats treated with C.calothyrsus leaf flour during pregnancy and lactation period. This study used a completely randomized design with 24 pregnant female rats which were divided into four groups i.e. control and treatments of 10, 17.5 and $25 \%$ of C.calothyrsus leaf flour in the diets. The treatment started from the first day of pregnancy until the young rats were weaned at the age of 21 days. Pancreatic histological structure of the mother showed an increase lack of normal tissue density and an increase connective tissues in the pancreas descriptively, especially at the highest level of C.calothyrsus leaf flour (25\%) in the diets.
\end{abstract}

Keyword: Calliandra calothyrsus, pancreatic histology, pregnancy, lactation

\section{INTRODUCTION}

The leguminous forage of red calliandra (Calliandra calothyrsus) is generally used for animal feed because the leaves, flowers, and stems have a high protein content of $20-25 \%$. Calliandra tannin is one of the highest compared to other legumes [1]. Tannins are polyphenolic compounds that can form complexes with other macromolecules.

Tannins are divided into two groups, tannins which are easily hydrolyzed and condensed tannins [2, 3]. Tannin has a large impact on the food nutritional value because in addition to its ability to bind proteins, it can also form complexes with various types of molecules i.e. carbohydrates, polysaccharides, celluloses, minerals, bacterial cell membranes, and enzymes involved in digestion of proteins and carbohydrates [4].

Utilization of calliandra can actually be used for nonanimal livestock including rabbits or poultry [1]. However, the high content of tannins, especially condensed tannins $(>10 \%)$ in C.calothyrsus, is a problem for non-ruminant animals due to their interaction with proteins. Research in mice given $20 \%$ of C.calothyrsus leaf flour in the diets showed that food intake or palatability remained high but all rats experienced weight loss [5]. Tannin can combine with proteins that cause it to be resistant to proteolytic enzymes or protease inhibitors. These compounds generally can inhibit trypsin, which is an activator of all enzymes released by the pancreas (zymogens).
The importance of the role of nutrition in animal reproduction has long been known. Poor nutrition can affect various stages of reproduction i.e. late puberty, reduced ovulation, low conception rates, high loss of embryo and fetus, length of anestrus postpartum, reduced milk, high perinatal mortality and low performance of the newborn. Based on the content of tannins which is quite high in C.calothyrsus leaf, it is necessary to do a research on the histology of rats pancreas which are given C.calothyrsus leaf in the diets during pregnancy and lactation.

\section{RESEARCH METHODS}

\section{Materials}

This research was carried out experimentally with a Completely Randomized Design (CRD). This experiment used adult female rats (Rattus norvegicus), 3 months old and body weight of 180-200 grams. Female rats were acclimatized in the laboratory, they were given commercial feed for one week and drinking water ad libitum. The estrus cycle was determined by observing the vaginal smear with Giemsa dyes, according to the procedure of Brancroft and Steven [6]. Vaginal smear samples were taken every morning. The estrus-determined female rats were put together in the same cage overnight with the male to be mated. If the vaginal plug is found in the next morning, the next day was declared as the first day of pregnancy [7].

Red calliandra (Calliandra calothyrsus) leaf samples were picked along the Mekarsari street, Baturiti area, Tabanan District, Bali Province, Indonesia. The samples 
were dried, blended and sifted into flour. The commercial standart feed for pigs was CP 551 (PT Charoen Pokphand Indonesia) which was mashed then mixed with the $C$. calothyrsus leaf flour according to the dose levels of the treatment.

The administration of $C$. calothyrsus leaf flour in this study consisted of four levels. The percentage of $C$. calothyrsus leaf flour in the diets was calculated as substitute for the commercial standart feed and carboxy metyl cellulose (CMC). CMC, a binder, was added $2 \%$ of total amount of the diets. Mixing feed was done by a mixer and a pelleting machine. The pellets were dried with a freeze dryer, then wrapped in plastic bags and stored in the refrigerator to keep the tannins content.

TABLE 1.

Calliandra calothyrsus LEVEL EQUIVALENT TO CONDENSED TANNIN CONTENT IN THE DIETS

\begin{tabular}{ccc}
\hline Level & $\begin{array}{c}\text { C. calothyrsus } \\
\text { leaf flour }(\%)\end{array}$ & $\begin{array}{c}\text { Equivalent to } \\
\text { condensed tannin } \\
(\mathrm{g} / 100)\end{array}$ \\
\hline $\mathrm{A}$ & $0 \%$ (control) & 0 \\
$\mathrm{~B}$ & $10 \%$ & 0.743 \\
$\mathrm{C}$ & $17.5 \%$ & 1.30 \\
$\mathrm{D}$ & $25 \%$ & 1.858 \\
\hline
\end{tabular}

\section{Treatments}

Twenty-four acclimatized female rats were randomly divided into four groups i.e. control group (without administration of $C$. calothyrsus leaf flour, only commercial standart feed was given) and three treatment groups which levels of $C$. calothyrsus leaf flour were $10,17.5$ and $25 \%$ in the diets, respectively. The pregnant rats were caged individually, the cage was cleaned regularly every four days. During the treatment, the diets were given based on the level treatments and according to the daily consumption needs of rat during pregnancy and lactation (20-30 grams/rats/day) every day at 17.00 of local times. The treatment started from the first day of pregnancy until the young rats were weaned at the age of 21 days.

\section{Pancreatic Histological Structure}

At the end of the treatments, the mother were sacrificed by an intramuscularly ketamine injection on the hamstrings, the animal then was dissected. The pancreas orgam was cleaned with $0.9 \% \mathrm{NaCl}$ solution and dried with tissue paper. The organ were stored in a Neutral Buffer Formalin, a fixative solution. Pancreatic histological preparations was carried out by the paraffin method and stained with Hematoxylin and Eosin (HE) staining method. Histological examination of the pancreas used an electric microscope with a magnification of 400 times. Histological slides were observed by using Optilab Viewer and Image Raster Software (Micronos version 2015). The qualitative data were analyzed descriptively.

\section{RESULTS AND DISCUSSION}

Plants naturally contain antinutrient compounds including those that have been widely studied as tannins. Apart from being an antinutrient compound, tannins are also known as a useful antioxidant compounds. Its role as an antinutrient or antioxidant is influenced by its presence in the food and by physiological conditions in the body. Tannins are compound of polyphenols which can form complexes with insoluble proteins [8].

The pancreatic gland is located across the back of the stomach from the duodenum to the spleen. This organ is divided into two parts, the exocrine part which produces digestive enzymes and endocrine parts that produce several hormones. The pancreas consists of two main types of tissue, (a) the acini, which secrete digestive enzymes, and (b) the island of Langerhans, which secretes insulin and glucagon hormones. According to Sloane [9], the exocrine part of the pancreas functions as the pancreatic acinar cell, producing pancreatic fluid secreted through the pancreatic duct into the small intestine. Exocrine pancreatic function is related with the biosynthesis and secretion of digestive enzymes, while endocrine function is related to hormone secretion related to carbohydrate metabolism.

The pancreatic histological preparation by Hematoxylin-Eosin (HE) staining showed that the cells of the acini gland producing digestive enzymes were darker than the islands of Langerhans that produce hormones. Observations on pancreatic histology showed that the higher the level of $C$. calothyrsus leaf flour in the diets, qualitatively showed the decrease in the amount of acini tissue compared to the control. In addition, more connective tissues were found in the pancreas with higher levels of $C$. calothyrsus leaf flour compared to control (Figure 1).

The results of this study were in line with previous research, that decrease in the normal tissue density and increase in the area of connective tissue in the pancreas showed low pancreatic capacity due to the low relative activity of digestive enzymes (amylases and lipases) in native chickens compared to broiler chickens at 1, 7,14 and 21 days after hatching [10].

Antinutrient substances in the form of tannins contained in $C$. calothyrsus leaf, with the main ability to bind proteins, caused the protein can not be digested. In many in vivo studies, protein digestibility is greatly reduced if the feed contains tannins [4]. The action of tannin is not only on feed protein but also on enzymes on the intestinal wall and protein in the saliva [5]. This would cause the pancreas worked harder because it increases the secretion of the protease enzyme to degrade tannin-protein complexes.

Anatomically, the structure of the pancreas would become hyperplasia and hypertrophy due to the enzymes oversecretion. In addition, the very strong binding of tannin-protein may cause proteins were not digested in the digestive tract and were defecated with feces, thereby reduced protein intake to the body. The main effect of tannin as a trypsin inhibitors is the excessive zymogen secretion of the pancreas, causing pancreatic hypertrophy 
and hyperplasia which is seen from an increase pancreatic weight.

Consumption of ingredients that contain toxic substances which affect the pancreas for a long time, as well as lack of protein in long term, was thought to be the cause of the Malnutrition Related Diabetes Melitus (MRDM). MRDM manifested in the blood sugar levels of white rat which reflected to the pancreatic organs damage [11]. Pancreatic damage are usually include both the exocrine and the endocrine parts of the pancreas. Pancreatic zymogen and RNA content will decrease because of severe damage to the histological structure of the pancreas i.e. irregular or incomplete forms of the acini, damage of epithelial cells (epithelium shrinking with unclear cell boundaries), fibrosis, fatty and calcified tissues [12]. Fibrosis is the formation of excess connective tissue in an organ or various tissue. The combination of tannin with protein caused resistance to proteolytic enzymes so that it can interfere with the work and function of the pancreas as a gland that synthesizes digestive enzymes.

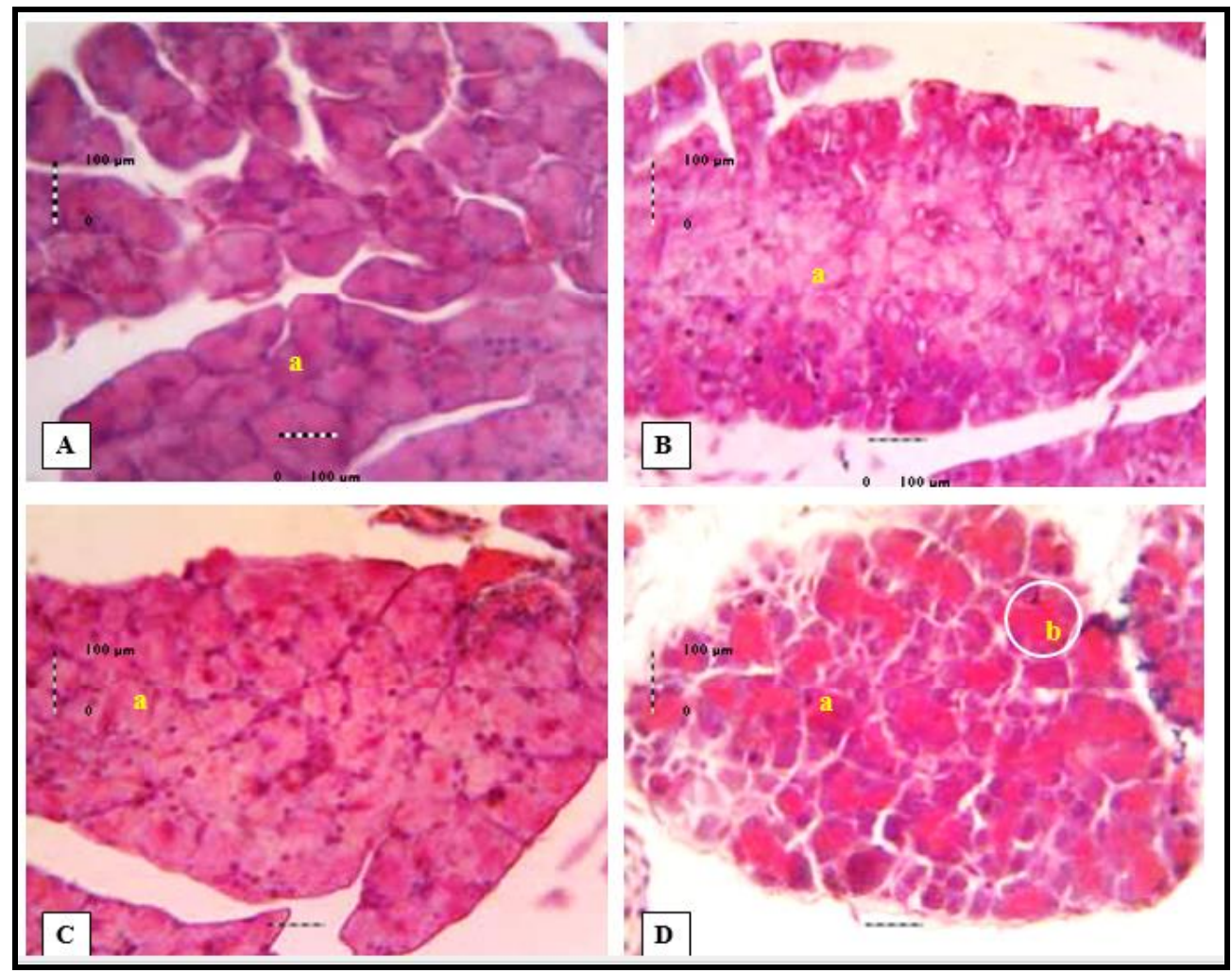

Figure 1. Histological structure of female rat exocrine (acini) pancreas.

Treatment groups of control (A), 7.5\% C. calothyrsus (B), 10\% C. calothyrsus (C), and 25\% C. calothyrsus (D) leaf flour level in the diet; (a) acini pancreas tissue, (b). enlarged of acini (darker lumen, oversecretion).

\section{CONCLUSION}

The higher the level of $C$. calothyrsus leaf flour in the diets which was consumed during pregnancy and lactation, showed the decrease in the amount of pancreactic acini tissue (reduced the tissue density) but more connective tissues were found qualitatively in the histology of female rat pancreas.

\section{REFERENCES}

[1] Wina, E., B.Tangendaja. 2000. Pemanfaatan Kaliandra (Calliandra calothyrsus) sebagai Hijauan Pakan Ruminansia di Indonesia, Prosiding Lokakarya Produksi Benih dan Pemanfaatan Kaliandra 14-16 November 2000 (Kerjasama ICRAF dan Winrock
International), Bogor, hal. 13-20.

[2] Waghorn, G.C., W.C. McNabb. 2003. Consequences of Plant Phenolic Compounds for Productivity and Health of Ruminants. Proc. Nutr. Soc. 62: 383-392.

[3] Wahyuni, H.I., N.P. Roxas. 2008. Comparative Study Of Pancreatic Enzyme Activity And It's Histology In Native And Broiler Chicks, Prosiding Seminar Nasional Teknologi Peternakan dan Veteriner 2008, hal. 678-683.

[4] Westendarp, H. 2006. Effects of Tannins in Animal Nutrition, Dtsch.Tierarztl.Wochenschr. 113: 264-268.

[5] Cannas, A. 2008. Tannins: Fascinating but Sometimes Dangerous Molecules, USA: Department of Animal Science - Cornell University. 
[6] Norton, B.W. 1998. Anti-Nutritive and Toxic Factors in Forage Tree Legumes, In: Forage Tree Legumes in Tropical Agriculture, The Tropical Grassland Society of Australia Inc. Queensland.

[7] Sitasiwi, A.J.2008. Hubungan Kadar Hormon Estradiol 17- $\beta$ dan Tebal Endometrium Uterus Mencit (Mus musculus) selama Satu Siklus Estrus, Available at: http://eprints.undip.ac.id/6192/1/agung

js, hubungan antar_kadar_hormon_estrogen_denga n kete\%E2\%80\%A6.pdf

[8] Kaufmann, M.H. 1992. The Atlas of Mouse Development, Academic Press Limited, London.

[9] Palupi, N.S., F.R. Zakaria, E. Prangdimurti. 2007. Metode Evaluasi Efek Negatif Komponen Non Gizi 1, Topik 6, Modul e-Learning ENBP, Departemen Ilmu \& Teknologi Pangan Fateta, IPB, Bogor.
[10] Sloane, E. 2003. Anatomi dan Fisiologi untuk Pemula, Alih Bahasa J.Veldman, Jakarta: EGC, hal. 290-291.

[11] Wahyuni, H.I., N.P. Roxas. 2008. Comparative Study Of Pancreatic Enzyme Activity And It's Histology In Native And Broiler Chicks, Prosiding Seminar Nasional Teknologi Peternakan dan Veteriner 2008, hal. 678-683.

[12] Bhatia, D., M.K. Gupta, A. Bharadwaj, M. Pathak, G. Khatiwas, M. Singh. 2008. Anti-diabetic Activity of Centratherum Anthelminticum Kuntze on Alloxan Induced Diabetic Rats, Pharmacologyonline 3:1-5

[13] Purnomo, M.T. 2010. Pengaruh Diet Singkong (Manihot esculenta) terhadap Struktur Histologi Pankreas Tikus Putih (Rattus norvegicus), Surakarta: UNS. 